\title{
VAMPIROLÓGIA, AVAGY A VÉRSZOPÁS TÖRTÉNETE
}

\section{VAMPIROLOGY, OR THE HISTORY OF HAEMOPHAGIA}

\author{
Galuska László Pál \\ ${ }^{1}$ Művészeti és Anyanyelvi Nevelési Tanszék, Pedagógusképző Kar, Neumann János Egyetem, \\ Magyarország \\ https://doi.org/10.47833/2020.3.ART.004
}

\section{Kulcsszavak: \\ vámpír \\ kultúra \\ horror \\ fantasy}

Keywords:
vampire
culture
horror
fantasy
Cikktörténet:
Beérkezett 2020. szept. 15.
Átdolgozva 2020. október 2.
Elfogadva 2020. október 7.

\begin{abstract}
Összefoglalás
Cikkünkben végigkövetjük azt a folyamatot, amelynek során a vámpir, mint kultikus alak megjelent a fantáziairodalomban. Értelmezzük a vámpírok kultúrtörténetét, vizsgáljuk megjelenéseiket egyes diskurzusokban, végül elkisérjük öket azon az úton is, amely a horror sötét kamráiból a fantasy kastélyáig vezetett. A vámpír ma már nem rém, hanem idol. Jó ez nekünk?
\end{abstract}

\begin{abstract}
In our article, we follow the process by which the vampire as a cult figure appeared in fantasy literature. We interpret the cultural history of vampires, examine their appearances in some discourses, and eventually accompany them on the path from the dark chambers of horror to the castle of fantasy. The vampire is no longer a specter but an idol. Is this good for us?
\end{abstract}

„A vámpírok egyszerre testesítenek meg az emberek képzetében démoni, ördögi, visszataszító teremtményeket és az emberi természet sötét vágyait, másrészt azonban érzékeny, szenvedélyes, szép, halhatatlan, erős és szabad lények."

\section{A vámpírok születése}

A vámpírok megjelenése az emberi gondolkodásban valamikor a kultúra hajnalán, az öskorban következhetett be. A pontos dátumot nem ismerjük, de mégis meg tudjuk állapítani, melyik lehet az a pillanat, amikor színre léptek. Mivel létezésük a nemléthez kapcsolódik, azidőtájt kellett, hogy alakot öltsenek, amikor gondolkodásunk először irányult a halálon túli világok felé.

Erre pedig akkor nyílt alkalom, amikor az animizmusnak nevezett ősvallás megjelent kultúránkban. Az animizmus a latin anima / animus - lélek / szellem szóból nyerte az elnevezését. Mivel a vallás (religio) mint kulturális tényező a hit és a rítus egyidejüségéből eredeztethető, ezért mindig vizsgálandó, hogy mi a meghatározó hitrendszere, és ehhez milyen rituálék kapcsolódnak. Az animizmus legalapvetöbb feltételezése - nevének is ez a forrása -, hogy az élölényeknek lelkük van, ami a halál után a túlvilágba távozik. A világot szellemek teremtették, és uralják (később ezek leghatalmasabbjait nevezték „isteneknek”), akik szintén túlvilágon élnek. Ekkor formálódott meg az évezredekig (de gondolkodásunkban tulajdonképp máig) ható világkép: a háromszintű univerzum eszméje. A meghatározó rituálék ezeknek megfelelően föleg a szellemek és istenek imádatára, illetve - a lélek megnyugtatása miatt - a halál utáni végtisztesség megadására irányultak. ${ }^{3} A$ vallás

\footnotetext{
1 Dr. Galuska László Pál. Tel.: +36 (30) 975290 7; fax: +36 (76) 483282 E-mail cím: galuska.laszlo@pk.uni-neumann.hu

2 Hume, Lynn \& McPhillips, Kathleen: "The vampire has become a sensual creature of passion and beauty, immortally young, powerful, and free of inhibition. The vampire is no longer the murderous demon, but a symbol of what humanity wishes it could be: fearless, immortal, indulgent, and powerful." [12]

3 Bővebben lásd: Animizmus szócikk [1]
} 
persze nem müködhet mitológia nélkül; a szellemek, az istenek és a túlvilág képe megjelent az animista eredetmítoszokban, de az ún. hősmítoszok is ekkor születtek.

Lényegileg az animizmusban bukkant föl elöször az éltető lélek és a túlvilág, s kezdődött el a gondolkodás arról, mi történik a lélekkel a testböl való eltávozás után. A lélek fogalmának megragadása is hosszú, szerves folyamat lehetett, amely szorosan kapcsolódott az emberi logika törvényszerüségeihez.

Az első lélek-koncepció [14] nagy valószínűséggel a leheletlélek lehetett. Alapja egyszerű megfigyelés: a holt lélegzete nem észlelhető tovább, tehát az éltető erő és a lélegzet ugyanaz. (Nem véletlen a magyar nyelvben a lélek, ill. a lélegzik, lélegzet szavak hasonló gyöke. De szólásainkban is megmaradt a lehelet-lélek hatása: pl. „kiadja a páráját”, „kileheli a lelkét”, stb.) A hal igetőnek és halfönévnek is azonos az alakja a magyarban: a halaknak ugyanis nem volt érzékelhető a lélegzete, így nem is tartották őket az élők világához tartozóknak, illetve lakóhelyüket, a vizet gyakran azonosították az alvilággal és az alvilági lényekkel. ${ }^{4}$

A következő lélek-koncepció alapja ismét elemi megfigyelés. Az élölények - ha vérüket kieresztik -megszünnek élni. Így született meg a vérlélek képzete. S mivel magát a vért a lélek hordozójának tekintették, számos kultúrában ebböl származnak a tabu-jellegü vértilalmak, s ezekhez kapcsolódva azon szörnyek is, akik a tilalom dacára a vért ellopják az élőktöl, hogy általa lélekhez jussanak: elöléptek a vámpírok, s megszülettek a hozzájuk kapcsolódó hiedelmek. A lélek és a test bonyolult viszonya, és a léleklopás, lélekszerzés motívuma azonban több viszonyrendszerben is megjelenik, olyan hiedelemvilágokban, amelyeknek látszólag nincs közük a vámpírokhoz.

$\mathrm{Az}$ árnyéklélek-elképzelés még mindig a vizualizációhoz kötődik: az élőlények körül ugrándozó, táncoló, "gazdája” minden mozdulatát követő, megfoghatatlan alak a mozdulatlan holttetem mellöl látszólag eltünik; nem csoda hát, hogy a logikus emberi elme előbb-utóbb eljutott arra a következtetésre, hogy a létezés valamilyen rejtélyes módon összekapcsolható az árny jelenlétével. Ennek a lélekfogalomnak a hatása is folyamatosan tetten érhető a nyelvben: a lélek (különösen a holtak túlvilágról visszatérő lelke) gyakran fejeződik ki az „árny”, „árnyék szóval. Érdekes adalék - valószínüleg nem is véletlen - hogy a vámpírnak mint élőhalottnak egyik alaptulajdonsága az árnyék, ill. tükörkép hiánya. Általában a rémtörténetekben újra és újra előjön a baljós árnyék vagy tükörkép toposza, amely hol eltünik (mint pl. J. M. Barrie Pán Péter-történetében), hol gazdája rovására túlságosan is megerösödik (mint pl. Andersen: Az árnyék c. mesenovellájában).

Végül pedig a legtöbb animisztikus vallás eljut a túlvilágra távozó lélek fogalmáig. A lélek a test halála után kibújik hasznavehetetlenné vált burkából, $s$ azt odahagyva örökös lakhelyére: a túlvilágba utazik. Azonban ezzel a történet még nem biztos, hogy véget ért.

\section{Halott test lélek nélkül: nekromancia}

A nekromancia (nekromanteia) = „halottjóslás”. Kezdetben nem a halott visszahívását, az élők közé bocsájtását jelentette, hanem inkább a mai spiritiszta szeánszokon tapasztalható halottidézést. Az egyik legrégebbi írásos példa, az endori boszorkány és Saul históriája a Bibliában található. Saul király azért kereste föl a vén nekromantát, mert tanácsot szeretett volna kapni az elhalt Sámuel prófétától a filiszteusok ellenében. A későbbiekben azonban a fogalom a holttestek „föltámasztását” a nekromanta mágus által történő „szolgálatba állítását” jelentette. A haiti woodoo vallás szubkultúrájában különösen nagy hatalmat tulajdonítanak a nekromanciának, varázsló praktikái által létrehozható egyfajta engedelmes holttetem, a zombi, aki szó nélkül teljesíti mestere kívánságait. A lélek nélküli hulla azonban veszélyes jószág: épp az emberi tényező, az emberi lélek tűnt el belőle: mozgatója valamiféle sötét, kiszámíthatatlan erő, mely könnyen irányítója ellen fordulhat. Mégis használták, használják a holtidéző praktikákat, kincskeresés, hatalomszerzés; az esetleges busás haszon reményében. Egyébként a nekromanta alakja szinte minden kultúrkörben ismert, egyes etimológiai értemezések szerint még a magyar népi hiedelemvilággal is összefüggésbe hozható: hazánkban ennek olasz változatából (nigromanzia) származik - némi torzítással - a „garabonciás”

\footnotetext{
${ }^{4}$ Számos mítoszban, pl. Manabus menominee törzsbeli történetében az alvilági szellemek, az anamaqkiuk okozzák az árvizeket. Jónás - Krisztus halálának előképeként - három napot tölt a víz alatt a cethal gyomrába zárva, stb.
} 
név. [9] A lélek nélküli tetem azonban nem él. Mozgási energiáját a mestertöl, illetve a mester által fölszabadított transzcendens erőktöl nyeri.

\section{Mesterséges test - mesterséges lélek; az ember a teremtő szerepében: Gólem}

A név eredeti jelentése: „nyers agyag”. A Gólem maga a teremtés, az emberelőttes, az ŐsÁdám, a (még) teljes lehetőség. Az első „gólem” maga Ádám volt, ám megjegyzendő, hogy ez a párhuzam azért mégsem teljesen jó: Isten nem szolgának, haszonállatnak, hanem lelkes lénynek teremtette Ádámot, lelket adott neki, s ebben az értelemben a „maga képére és hasonlatosságára” formálta. Mindenesetre a Szentírás használja a kifejezést a lélek előtti test kifejezésére.

"Látták szemeid az alaktalan testemet (szó szerint: amikor még Gólem voltam), és könyvedben ezek mind be voltak írva: a napok is, a melyeken formáltatni fognak, holott egy sem volt meg közülük." (Zsoltárok könyve, 139.16.)

Ebben az értelmezésben a Gólem alaktalan test, formátlan szubsztancia, a még nem elkészült edény. Nyilvánvalóan a bibliai hagyomány alapján jött létre a héber hiedelemvilágban a megelevenített engedelmes agyagszörny motívuma, ${ }^{5}$ azonban a leghíresebb és legtöbbet földolgozott (s a későbbi szörnyeteg-képzetekre is legnagyobb hatású) változat a XVII. századi prágai zsidósághoz köthetö.

Eszerint Gólemet Líva (Juda) ben-Becálel prágai rabbi (megh. 1609) alkotta meg, aki kabbalisztikai tudománya által életet lehelt belé, s a zsidó népmonda szerint, mindennemü szolgálatot végeztetett vele. Müködtetéséhez egyes változatok szerint homlokára Isten egyik

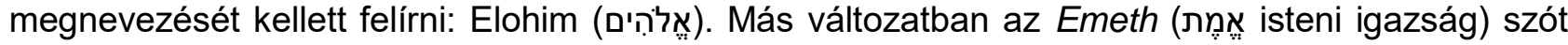
kell az agyagba karcolni, amelyböl az alef-jelet (אֶ) kitörölve a szó a Meth vagy Mét (מֵ halott) kifejezésre változik. Így lehet elpusztítani.

Ismét egy másik változat szerint a rabbi ismerte Isten titkos nevét. Ezt ráírta egy pergamendarabra, amit beledugott az agyagszörnybe vágott résbe (vagy annak szájába). Ha a pergament kihúzta, Gólem ismét élettelen agyagtömeggé vált. Maradványai állítólag még ma is fellelhetők a prágai Altneu-zsinagóga padlásán. A zsidó népéletben Gólem annyit tesz, mint „bárdolatlan, együgyű ember”. ${ }^{6}$ Több korabeli népkönyv is készült történetéböl. [15] A figura ismét csak az emberi tudálékosság és felelőtlenség egyik kifejeződése: bármilyen jó szándékkal próbálkozzon is az ember a teremtés utánzásával, eleve kudarcra ítéltetett, mivel teremtményeinek nem adhat lelket, $s$ anélkül az általa létrehozott kreatúra csupán lélektelen gép, vagy sötét hatalmak által mozgatott szörny lehet csupán.

\section{Emberből Gólem: Frankenstein szörnyetege}

A Gólem-toposz és a lélek nélküli emberforma szörny-test talán még ikonikusabb megjelenése Mary Shelley: Frankenstein, avagy a modern Prométheusz c. rémregényében érhető tetten. Szerzője nem kevésbé érdekes, mint maga a mü.

Mary Wollstonecraft Godwin Londonban született 1797. augusztus 30-án. Apja, William Godwin egyike az első angol anarchistáknak. Édesanyja a korai feminizmus angliai előfutára, Mary Wollstonecraft, aki gyermekágyi lázban hunyt el.

A kis Mary gondos (bár nem éppen tradicionális) nevelést kapott. Olvasmányai közé tartoztak Milton, Locke és a francia felvilágosodás úttörőinek írásai. Percy Bysshe Shelley (Godwin híve és tanítványa) megszöktette az akkor tizenhat éves lányt, és a mostohanővérét, majd 1816-ban Svájcban csatlakoztak a számüzött Lord Gordon Byronhoz. A két költő egyszer hajnalig vitatkozott a Zeusz ellen lázadó Prométheuszról (Shelleyt ateizmusa miatt zárták ki Oxfordból). Ezért lett Mary regényének alcíme $A$ modern Prométheusz. (Megemlítendő, hogy Percey Shelley is írt egy nem kevésbé lényeges művet, $A$ megszabadított Prométheusz címmel, amelyben Prométheusz győz, és Zeuszt a Végzetes Óra allegorikus alakja letaszítja olümposzi trónjáról.)

Maga a Frankenstein c. regény 1818-ban született a Genfi tó partján álló Diodati villában. Itt került sor egy kis összejövetelre, amelynek résztvevői Maryn kívül Lord Gordon Byron, a háziorvosa,

\footnotetext{
${ }^{5}$ Erről bővebben lásd: Deutsch Tibor cikkét. [5]

${ }^{6}$ Erről ír Deutsch Tibor, illetve a Gólem szócikk [2]
} 
James William Polidori, Claire Clairemont, és Percy Bysshe Shelley (Mary vadházastársa) voltak. $A z$ este folyamán fölmerült egy rémregény-paródia megírásának ötlete. Mindenki visszavonult az alkotáshoz, ám a társaságból egyedül Mary Shelley fejezte be a munkát, ami végül a legkevésbé sem parodisztikus müvet eredményezett.

Mary apja maga is írt gótikus rémregényeket, ill. Byron olvasott egy Fantasmagoriana c. horrortörténetet. A Frankensteint Göncz Árpád fordította magyarra 1977-ben. ${ }^{7}$ Számos méltatója szerint a történet a modern sci-fi elözményeként olvasható. ${ }^{8}$

„Frankenstein szörnye nem az első, ember által létrehozott teremtmény (klasszikus példa a Gólem), de mindenképpen a legfontosabb a science fiction, mint a tudomány hatásait vizsgáló irodalom számára, hiszen elődjévé válik minden mesterségesen létrehozott lénynek: robotoknak, kiborgoknak, klónoknak." -írja róla pl. Takács Gábor. [23] [15]

Azonban a probléma nem csupán a teremtő és a teremtmény viszonyában gyökeredzik, hanem sokkal inkább abban, hogy az emberre hasonlító értelmü, de alkotójánál erősebb és hatékonyabb kreatúra nem rendelkezik emberi lélekkel, s ezért nem illeszkedhet be az emberi társadalomba, nem értheti meg igazán alkotóját, s végső soron veszélyessé válik. ${ }^{9} \mathrm{Ez}$ a problémakör kívül vezet bennünket a puszta erkölcsiségen, s a transzcendencia azon területeire irányítja figyelmünket, amelyeket már nem lehet tudomány-etikai felvetésekkel értelmezni.

\section{Lélek test nélkül: kísértet (visszajáró holt)}

Az eddigiekben olyan testekröl esett szó, amelyek lélek nélkül (vagy valamely gonosz erő által megszállva) müködtek, a továbbiakban a test nélküli lélekhez kapcsolódó hiedelemrendszerekkel folytatjuk gondolatmenetünket.

Pócs Éva etnográfus szerint a közép-európai népi hagyományban több lélekképzet van:

1. Hasonmás, vagy árnyéklélek-képzet. Ez el is szakadhat a tulajdonosától, ill. halála után szellemként élhet tovább. Megjelenhet fizikai „anyagi” formában, vagy „fantomtestként” is. Mindkét esetben képes lehet pl. állattá változni. [16]

2. Visszajáró halott-képzet. Ennek kétféle típusa van, az egyik családtagjainak segítségére lenni igyekszik, a másik saját vagy családtagjai, ismerősei bűnei miatt nem nyughat, és ártalmára akar lenni az élőknek. [4] A szellemek már a kereszténység előtti forrásokban is ambivalens lények, lehetnek rosszindulatúak, de jóindulatúak is, támogatásukat mindenesetre áldozatokkal meg lehet nyerni. Az „idegen” túlvilági látogatók között megemlítendőek még a halott családtagok, ősök visszatérései is, ezek szintén „jó”, illetve „rossz” halottként differenciálódtak: védhették leszármazottaikat, falujukat mint őrzőszellemek, vagy rátámadtak közösségükre mint ártó démonok. [17] A halottak visszajárásai részint időszakokhoz (nyugaton a téli napforduló, ill. november 2. táján, Kelet - Délkelet-Európában az ortodoxia területén húsvét és pünkösd idején), részint konkrét eseményekhez, elintézetlen ügyekhez kötődnek. Utóbbi esetekben a halottak mint „óvó, sorsirányító, tabu- és szankciólények" térnek vissza. Lehetnek védő és vezérlő szellemek, de visszatérhetnek vihardémonként, ártó szellemként. [16]

A kereszténység elterjedése után Európában és Magyarországon a visszatérö halottakat két alapvető csoportba sorolták: a mennyországból vagy purgatóriumból elintézetlen ügyük miatt visszalátogató ,jótét lelkek”, illetve a pokolból feljövő kárhozott lelkek, vagy a halott alakját felöltő démonok, azaz „kísértetek” csoportjába. Pócs Éva más elnevezést is említ: „visszajárók” és „kísértetek”.

„A kora középkor óta ismert - sőt ókori adatok által is képviselt - általános európai hiedelmek szerint az élők világába látogató kísérteteknek két fő csoportja van. - írja Pócs. Egyrészt a haláleset után a családjukhoz visszajáróké, akik félbemaradt, elintézetlen ügyeiket kell, hogy rendezzék

\footnotetext{
7 A történet szerint Victor Frankenstein, a tehetséges ifjú tudós, holt emberek testrészeiből hoz létre egy emberformát, s galvanikus módszerekkel megeleveníti. Amikor műve öntudatra ébred, a tudós borzadva elmenekül, ráébredve felelősségére. Ám a teremtmény követi mesterét, számon kéri rajta létezése értelmét, majd bosszúból kiirtja Frankenstein szeretteit.

8 Kifejti: Takács Gábor. [23] Lásd még: Pivárcsinál is. [15]

${ }^{9}$ Ez persze csak a mű egyik olvasata. A másik szerint alkalmas lett volna az emberhez mindenben hasonló életet élni, de az embertelen bánásmód gonosszá tette. A másik alapvető elem az értelmezésben az Istenné válni akaró ember dölyfének büntetéseként tekinthet a szörnyre, és ezt ráolvashatjuk a Shelley-k tragikus sorsára, vagy Byron halálára is.
} 
hozzátartozóikkal: ők a visszajárók. A másik csoport a személytelen, konkrét családi kapcsolataikat és egyéniségüket már elvesztett kísérteteké..." (Kiemelések tölünk.) Az elnevezés itt tehát a szellem egyéniségének megőrzését vagy elvesztését tükrözi. [18]

\section{Vámpírok}

Mindezek alapján a vámpírt úgy határozhatnánk meg, mint visszajáró holttetemet, amely részben megörzi korábbi identitását, bár vannak kísértetszerü tulajdonságai is. Energiájához újra és újra föl kell töltekeznie lélekkel. Azonban a „felhasznált” lélek nem származhat akármilyen forrásból, csakis értelmes lény - ember - lelke lehet, amelyet a szörny a vér segítségével szerez meg magának.

De miért nem jó akármely élölény vére lélekpótléknak? Ennek megértéséhez több vallási és filozófiai rendszert kell segítségül hívnunk.

Az ókori pogány görögség gondolkodásának enciklopédikus igényességü szintézise Arisztotelész görög filozófus nevéhez füződik. Arisztotelész három lélekfogalmat különít el:

1. növényi (vegetatív) lélek,

2. az állati (animális) lélek

3. szellemi (spirituális) lélek.

A héber hittudomány felfogása szerint a Bibliában csupán két lélekfogalom található, az arisztotelészi értelemben vett növényi lélek-elképzelésnek nincs nyoma, a Szentírás csak az állatoknak és az embernek tulajdonít lelket.

A talmudista - s az ennek logikájából kisarjadó kabbalista - elképzelések szerint viszont az embernek öt különféle lelke van:

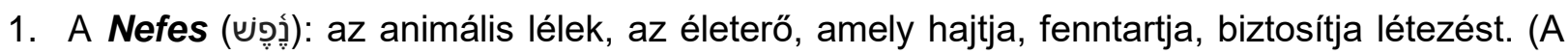
Bibliában csak állatokkal kapcsolatban használják külön.)

2. A Ruach (רוn): szellemi lélek, ez istentöl, a Szent Szellemtöl / tulajdonképpen a Szentlélektől) származik. Ez adja az értelmet, és a kapcsolatot a spirituális világgal. Magában foglalja az erkölcsöket, valamint a jó és a rossz megkülönböztetésének képességét. Székhelye a szívben van.

3. A Nesámá (נשמה): halhatatlan (lehelet) lélek, amely az ember halálával visszaszáll Istenhez. Ez különbözteti meg az embert az összes más létformától. [19]

4. A Chájá (חיה): az örök élet lelke, amely a transzcendencia felé való nyitottságot és a hitet hordozza.

5. A Jechidá (חידה): A lélek esszenciája, amely a legföbb kapcsolatot jelenti a Teremtővel. [7]

A vámpír csak a vérlélekhez (nefes) tud hozzájutni, mivel már a ruach is a Szentlélektől származik. Ugyanakkor a vérlélek embertől történő eltulajdonítása teszi képessé arra, hogy élőként cselekedjen, és értelmét is megőrizhesse. Bár a vér a lélek legprimitívebb minősége, mégis ez működteti a fölöttes szinteket, ezért a mózesi törvények a legszigorúbban tiltják bármely élölény vérének fogyasztását. Ezt a tilalmat szegi meg a vámpír, s ezáltal válik a káosz és a sötétség, a teremtéssel szembeszálló ördögi hatalom eszközévé. A vámpírlét az önzés ördögi szint alatt álló foka: míg a sátáni erők a teremtést elvi, szellemi alapon támadják, ${ }^{10}$ a vámpír a puszta létezés vágyától üzve fordul szembe az isteni renddel. Ezért nem létezhet „jó” és „lelkiismeretes” vérszopó: a vámpírnak nincs lelke, tehát lelkiismerete sem lehet.

\section{A vámpírkultusz szülőatyja}

A vámpírkultusz első modern kori fölerősödése egyértelműen egy ír-angol szerző: Bram Stoker: Dracula (magyarul: Drakula gróf válogatott rémtettei) c. regényének köszönhetö. Stoker a kora-középkori kódexeket őrző méltán híres könyvtáráról ismert dublini Trinity College hallgatója volt, tanulmányai befejezése után Londonba települt, ahol írással próbálkozott. Személyesen ismerte a kor szórakoztató irodalmának olyan vezéralakjait, mint Robert Lewis Stephenson vagy Arthur Conan Doyle, s maga is próbálkozott lektürök írásával. Legsikeresebb műve a Drakuláról írt

\footnotetext{
10 Legalábbis ezt a képet sugallja róla Milton Elveszett paradicsoma (1669).
} 
vámpírregény, amely azonban igazi világhírnévre csak halála után tett szert. Műve az angolszász filológia rendszertanában gótikus horrortörténetként van besorolva.

Stoker forrásául a londoni British Museumban folytatott intenzív kutatásai kínálkoztak, de nagy hatást tettek rá Vámbéry Ármin magyar néprajzkutatóval folytatott beszélgetései, a Londont ekkoriban izgalomban tartó Hasfelmetsző Jack-féle megoldatlan gyilkosságsorozat, illetve barátsága az irodalmár és felfedező Richard Burtonnel, aki tizenegy hindu vámpírtörténetet fordított le angolra. Stoker saját bevallása szerint egyszer igen sokat fogyasztott vacsorára fött rákokból, $s$ ezt követően komplex rémálma volt egy „vámpírkirályról”. Ennek hatására fogott művébe. A történet főszereplője Vlad Dracul Ţepeş havasalföldi oláh hoszpodár (vajda), aki iszonyú kegyetlensége és még a machiavellizmus felöl szemlélve is égbekiáltóan opportunista volta miatt vált hírhedté már a saját korában, a XV. században. ${ }^{11}$ Mivel Erdély a Magyar Királyság része, így Nyugat-Európában a közvélemény gyorsan összekapcsolta a rémvajda alakját Magyarországgal és Erdéllyel.

Stoker interpretációja szerint Drakula ördögi praktikák folytán élöhalottá vált, és sajátos létezését évszázadokig fent tudta tartani, ezalatt emberfeletti müveltségre téve szert. Mivel Erdélyben már egyre nehezebben jut hozzá a fennmaradáshoz szükséges gyanútlan áldozatokhoz, elhatározza, hogy székhelyét az embermillióktól nyüzsgő Londonba helyezi át. Ehhez azonban segítségül kell hívnia egy angol ügyvédet. Innen indul a történet, amely - a hitelesség és a kellő fantasztikus hatás érdekében - napló- és levélregényként lett megírva, ${ }^{12}$ karakterei levelezése és naplójegyzetei alapján kibontakozó cselekménnyel.

Az ifjú ügyvéd, Jonathan Harker Drakula gróf meghívására érkezik egy elhagyatott kastélyba, az erdélyi Kárpátok hegyei közé, ahol a szörny csapdába ejti, és kis híján meggyilkolja őt. Harker végül kiszabadul a gróf rabságából és nagy nehezen hazavergődik, de Drakula követi őt Angliába, miközben útját rejtélyes halálesetek jelzik. Londonban a gróf az ifjú ügyvéd menyasszonyát, Minát és annak barátnőjét, Lucyt is befolyása alá vonja, utóbbit meg is öli, és halála után őt is vámpírrá teszi. A regény arról a nyomozásról szól, amit Harker, Van Helsing doktor és Mina folytatnak, hogy rájöjjenek, ki ez a rém, és hogyan lehet öt elpusztítani, ami végül sikerül is. (Stoker volt az elsö ismert író, aki kidolgozta az azóta számtalanszor utánzott vámpírkaraktert, melynek fő gyengeségei a fokhagyma, a napfény és a szívbe szúrt kihegyezett karó.) [23]

\section{Drakula múltja}

Stoker Drakula gróf alakjában olyan évezredes szorongások, félelmek és tabuk láncolatát hozza összefüggésbe, amelyeknek eredete a történelemelőttiség homályába vész. Mégis, ezek érzékelhetöen testet öltenek regényében. Gondoljunk pl. azokra az ifjú Harkert Drakula várkastélyában megkörnyékező démonian gyönyörü és veszélyes vámpírhölgyekre, akik a vampirizmus feminin vonásait jelenítik meg.

„Nem voltam egymagam egyszer csak. A szoba nem változott, amióta beléptem: a holdvilágnál még lépteim nyomát is láthattam a padló porában. A holdfény körében azonban három fiatal hölgyet pillantottam meg. Ruhájuk s viselkedésük szerint úri kisasszonyok lehettek. Álmodhattam öket mégis? Mert hiába világított mögülük a hold, árnyékot nem vetettek. A közelembe óvakodtak, elnézegettek egy darabig, majd összesúgtak. Kettő fekete hajú volt és sasorrú, akár a gróf. Merö tekintetüket követve azt láttam, hogy a szemük szinte vörös a hold nyájas világánál. A harmadik szőke volt, zuhatagos aranyszőke, és a szeme akár a mély tüzü zafír. Mintha ismerős lett volna az arca valamelyik nyomasztó álmomból. Fehér foga ragyogott mind a háromnak, mintha gyöngysort tettek volna csábos ajkaik közé. (...) A szöke odalépett, fölébem hajlott, már a leheletét éreztem a börömön. Édes lehelet volt, mézédes, de ahogyan kacagásának ezüstje mögül üveg csengését hallottam, a mézben csömörletesség sejlett, akár a vér szagában." [21]

A semmiből előtűnő három nőalak a görög mitológiából ismert empusza, más néven a brukolakhosz figuráját vetíti elénk. Az empuszák Hekaté istennő kísérői. Szép ifjú leány alakjában jelennek meg, de szamárfarúak, és az egyik lábuk (vagy a sarujuk) bronzból van. A görög mitológia vérivói közé tartozott még Lamia is, akit gyönyörü hercegnőből változtatott szörnyeteggé Héra

\footnotetext{
11 Drakula alakjának változásait a korabeli röpiratokban sokan vizsgálták, de ez most nem jelen munkánk tárgya.

12 Itt jegyezzük meg, hogy a Frankenstein is levélregény.
} 
féltékeny dühe. Lamia szépségével elcsábította a hiszékeny férfiakat, azután kiszívta életerejüket. Gyakran ábrázolták félig leány-félig kígyótestű monstrumként.

A kereszténység előtti elemek mellett Stoker bőségesen merít a balkáni, leginkább a román népi hiedelemvilágból is. Az ortodox görögkeleti vallás tanítása szerint, aki a kiközösítve hal meg, az visszajáró halott, "moroi" lesz mindaddig, amíg az egyház föl nem oldozza az átok alól. Keletbalkáni helyi babonák megemlékeznek továbbá egy strigoi nevű vérivó, emberfejü madárról is, nyilvánvalóan a pogány görög hárpüák kései maradékaként. [15] [10] A strigoi alakja nem volt ismeretlen a középkori Magyarországon sem: Könyves Kálmán királyunk nem a boszorkányok, hanem a strigák létezését tagadja törvényeiben. ${ }^{13}$ Szintén a balkáni vámpírbabonák között szerepel az a nézet, hogy bizonyos embereknek (pl. a törvénytelen vagy meg nem keresztelt gyermekeknek, illetve a hetedik fiúk hetedik fiainak) végzete, hogy vámpírrá legyenek. Néha vámpírság gyanújába keveredik az, aki visszautasítja, hogy fokhagymát egyen.

Tévedés lenne azonban azt hinni, hogy a vámpírok alakja csak a Balkánhoz kötődött. NyugatEurópában is bőven akadtak a vérszopókkal kapcsolatos mendemondák, jó példa erre a német területeken ismert nachzehrer (lepelzabáló, élöhalott, csámcsogány) alakja is. [10] A nachzehrer a hiedelem szerint - abból az emberből lesz, aki járvány idején először válik a ragály áldozatává. Temetése után az illető feléled a koporsójában. Ellenállhatatlan éhség gyötri: először fölzabálja a halotti leplét, azután lerágja saját végtagjait. Ezt követően ásni kezd a föld alatt, mint a vakond, áthatol a szomszédos sírokba $\mathrm{S}$ az ott talált maradványokat is elfogyasztja. Csöndes estéken a sírhantok alól egészen az élők világáig fölhallatszik mohó csámcsogása. A fö gond az, hogy amíg a nachzehrer táplálkozik, a környéken tovább dühöng a járvány: a szörnyeteg így gondoskodik kellö számú halottról, akikböl aztán szabadon lakmározhat.

Elpusztítása nem túl bonyolult. A nachzehrer-vadászt a rém csámcsogása vezetheti nyomra. Úgy tűnik, hogy a sír felnyitása után a nachzehrer könnyen azonosítható. A hagyomány szerint meglehetősen sajátos módon fekszik a koporsójában: egyik hüvelykujját (amennyiben még megvan) a másik kezébe fogja, a bal szemét pedig mindig nyitva tartja. Megsemmisítéséhez elég, ha levágják a fejét: még egyszerübb azonban az a módszer, amelynek értelmében, a járványban elsőként elhalt áldozatnak követ, téglát tesznek a szájába: így nem tudja elkezdeni a zabálást, és nem tud élöhalottá válni. [6]

A vámpírok alakját a XVIII. századtól kezdték Európa szerte hozzákapcsolni a Magyar Királysághoz. ${ }^{14}$ A Habsburg-török háborúk kapcsán ekkoriban három bőségesen dokumentált vámpírbotrány is lezajlott hazánkban: a kisolovai (1725), majd a medvédiai eset (1731-32), [10] végül a deési vámpírper (1742).

Kisolován egy Plogojovicz Péter (Petar Blagojević) nevű földműves halála után kezdődtek a vámpírtámadások. Az elöljáróság Plogojovicz sírját felásatta, és az ismert módszerekkel (karó és a tetem elégetése) a vámpírt deaktiválta. A szemtanúk egybehangzóan állították, hogy a sír felnyitásakor Plogojovicz tetemének egyáltalán nem volt hullaszaga. A haja, szakálla, és a körme a sírban újra kinőtt, a böre lehámlott, és friss került a helyére. A karó beszúrásakor a halott szájából hörgő hang hallatszott, és orrából-füléböl dőlt a friss vér. A jegyzőkönyv „egyéb durva jelenségekröl” is szót ejt, amelyeket azonban nem óhajt részletezni.

A Nándorfehérvártól nem messze fekvő, a török időkben teljesen elszerbesedett Medvédia a török kiüzése után a Habsburgok belgrádi föparancsnokságának felügyelete és Savoyai Jenő közvetlen irányítása alatt állott. A községben egy Arnold Paole nevü hajdú került halála után vámpírgyanúba. A katonai hatóság a sorozatos lakossági bejelentések miatt előbb Glaser nevü medikusát (keresztneve a forrásokban nem szerepel), majd Johannes Flückinger föfelcsert küldte ki a helyszínre, akiknek jelentései az eddigi leghivatalosabb dokumentumok a vámpírperek történetében. Mindketten megállapították, hogy a feltárt sírokban megszemlélt tetemek egy része bomlatlan állapotban találtatott, börük friss volt, sőt, egy Milica nevű asszony még hízott is a sírban. Végül mindkét hadgyógyász azt javallotta a katonai hatóságoknak, hogy a lakosság nyugalma érdekében engedélyezzék a helybeliek számára a vámpírgyanús testek elégetését. Az engedélyt

\footnotetext{
13 „de strigis vero, quae non sunt, ne ulla quaestio fiat” - boszorkányok ellen pedig, minthogy nincsenek, semminemű kereset ne legyen. Azonban ezzel a király csak a strigák létét tagadta. Ugyanezen dekrétum 60 . bekezdésében elrendeli, hogy azok, akiket az esperes és az ispán hírével, tudtával rontóknak (malefici) találtak, elítélendők. Bővebben lásd: Tóth Béla könyvében. [24]

14 Vlad Tepes persze Mátyás lovagja volt, aki foglyul is ejtette, Tepes vára pedig Erdélyben van, tehát a kapcsolódás régebbi eredetű, de az európai közvélemény számára mégis a XVIII. században vált közhelyszerüen elterjedtté.
} 
megkapták. Az eset azért lett szerte Európában ismertté, mert Glaser édesapja, a bécsi Johannes Friedrich Glaser a fia által küldött jelentés másolatát továbbította a nürnbergi Commercium Litterarium folyóirat számára. [10] [20]

A deési (dési) vámpírper 1742-ben esett meg, és erröl peres jegyzőkönyvek is fennmaradtak. Ráth-Végh István közöl is ezekböl részleteket. Az alábbiakban olvashatjuk azt a határozatot, amelyet a deési városi tanács fogalmazott meg, azok után, hogy 1742 augusztus 2-án írott megkeresésükre Kolozs vármegye elöljárósága megadta az engedélyt a vámpírgyanús deési személyek exhumálására.

„A sírból kijáró két suspecta persona iránt concludáltatott, hogy csak felásattassanak, úm. 1. Pila Bába, 2. Szabó Miklós János. Ezeknek felásatásokra exmittáltatnak Senator Boda Szabó András stb. stb. atyánkfiai, kik is még ma felásattassák őket, kik is investigálják serio, ha azon suspicio iránt való critériumok, úm. ha arculatjában pirosság vagy valami elevenség, s a karónak beléjek való verettetése után valami vérnek kiütése a karó nyoma után comperiáltatnak-é, és egyéb criteriumokat, ha miket observálnak, a ts. ns. Tanácsnak reportálni tartsák magok kötelességeknek. Minthogy penig ezen feljebb írt suspecta személyekben a megírt criteriumok, felásása után Bába Pilában bizonyosan comperiáltattak, azért concludáltatott, hogy sírjából kivétessék, és a törvényfához vitessék, s ott hóhér által megégessék. A többi felásatandókkal is hasonlóképpen kell cselekedni, ha a szerint comperiáltatnak, secus visszatemettessenek." [20]

Ekkor már I. Ferenc császár is beavatkozott az ügybe, és rendeletben tiltotta be a vámpírperek minden formáját a Német-Római Birodalom és az összes társult királyság, valamint a tartományok területén. Ez a tiltás végül azt eredményezte, hogy az 1740-es évek közepén a vámpír-hisztéria birodalomszerte általánossá vált, és a Magyar Királyság neve jó időre összekapcsolódott a vérszívók aktivitásával.

\section{Védekezésformák}

Ilyen előzmények után érthető, hogy Közép- és Kelet-Európában a vámpírok elleni védekezésnek számos formája alakult ki.

\subsection{A vámpír elriasztása, ártalmatlanítása}

1. Ostya, olvasó, kereszt a vámpír szájába (németek).

2. Tárgyak a sírba - halászháló, magvak, stb. hogy a halott azokat számolgassa, bogozza, és megfeledkezzék az élőkröl (németek).

3. Fokhagyma, tehéntrágya, parfüm, szentelt víz, dióhéj, levendula, emberi ürülék - ezek szagát a vámpír nem állja (több területen is elterjedt).

4. Tövises gally, fokhagymakoszorú az ablak köré (ettől nem tud bejönni) vagy borókagally (lecsillapítja - több területen is elterjedt).

5. Fekete kutya, fekete kakas -ezek elriasztják (már az ókori görögök is ezekkel védekeztek a rossz szellemek ellen).

\subsection{A vámpír eliminálása}

1. A vámpírgyanús test disznózsírral bedörzsölése (Havasalföld).

2. Tóba, pocsolyába, szakadékba dobás (oroszok).

3. Tánc a halottal (Moldva).

4. Láblevágás, lábégetés, szemkiszúrás (bolgárok).

5. Szög a fejbe, kö a szájba (Velence, Szilézia, stb.).

6. Sarló a nyakra - ha megmozdul, saját fejét vágja le (Szerbia).

7. Dekapitáció, karó a szívbe, a test elégetése (lengyelek, bolgárok, románok, később németek, csehek és mindenhol).

8. A lengyeleknél karó kerülhetett az ülepbe is.

9. Magyarok: belelőni a sírba (később ezüst golyóval).

10. Egyházi átok, exorcizálás, stb. (mindenütt). 
11. Vámpírjelek keresése a sírnál (megsüllyedt sír, félreesett kereszt, fénynyaláb a síron, vámpírkémény - lyuk a sírhant mellett). [15] [10]

\section{Stoker vámpírmodellje: a történelmi III. Vlad Dracul (Ion Drăculea Tepeş 1436 Segesvár - 1476 Bukarest)}

III. Vlad Dracul havasalföldi hoszpodár családja Zsigmond magyar király és német-római császár korában vette föl a Dracula (Drăculea) elönevet. Zsigmond az általa alapított Szent György lovagrendbe politikai okokból havasalföldi és moldvai bojárcsaládok tagjait is befogadta, akik szerfölött büszkék voltak arra, hogy a hatalmas nyugati uralkodó ilyen megtiszteltetésben részesíti őket. A lovagrend jelképe egy saját farkába harapó kis sárkány (latinul: dracula) volt, s a boldogságban úszó bojárok siettek beilleszteni családnevükbe a szót.

Vlad apja, II. Vlad Dracul, Hunyadi János vazallusa a várnai csatában. Ám, mivel később szövetséget kötött a szultánnal, a kormányzó megölette, és az ellenlábas Dăneşti famíliának adományozza a vajdaságot. Vlad bátyját, Mirceát saját emberei nyúzták meg, és temették el egy trágyadomb alá Târgoviștében. (Egyes változatok szerint megvakították, majd élve elégették.)

III. Vlad török segítséggel került trónra, majd azonnal a szultán ellen fordult. Később, amikor egyéb bünei miatt Mátyás elfogatta, II. Pius pápai követe 1462-ben a következőket jelenti külsejéröl:

„... termete nem magas, de igen izmos és erős, külsőre kegyetlen és félelmetes, sasorra igen nagy, tág orrlyukakkal, arca pedig sovány és sápadt, hosszú szempillái tágra nyílt kék szemeit övezték, fekete és sürü szemöldöke fenyegetővé tette nézését, bajuszán kívül arcát és állát borotválta. Kiugró homlokcsontjai növelék fejének méreteit. Magas tarkóját bikáéhoz hasonló nyaka kötötte széles vállaihoz, melyre fekete, göndör hajfonatok hullottak."15

Amikor megszerezte a hatalmat, a legenda szerint országa összes koldusát meghívta ebédre, majd megkérdezte tölük, szeretnének-e megszabadulni szegénységüktöl. Igenlő válaszukra bezárta őket abba a hatalmas pajtába, ahol teríttetett nekik, és rájuk gyújtatta az épületet. Azt beszélik, hogy ezek után egyetlen koldus sem akadt Havasalföldön egész uralkodása alatt. Következő hírhedt tette az volt, hogy tanácskozásra szólította országa bojárjait. A tanácskozás során arról érdeklődött, hogy a jelenlévők hány hoszpodár uralkodását tudják felidézni. Még a legfiatalabb bojárok emlékezetében is több vajda szerepelt, mert Havasalföldön és Moldvában is igen gyakori és brutális módon zajlottak a hatalomváltások. Vlad elöször biztosította őket, hogy ő lesz az utolsó uralkodójuk, majd azonnal elfogatta, és válogatott kínzások közt (karóba húzás, nyúzatás, lefejezés) mindet elpusztította.

1459-ben beszüntette az adófizetést a törököknek, ugyanekkor szövetséget kötött Mátyás királlyal. A szultán 1460-ban Hamza basát küldi hozzá követségbe (más források szerint azért, hogy hogy letartóztassa). Dracula a basa egész kíséretét karóba húzatta, a basának pedig - mivel nem volt hajlandó megemelni előtte - fejéhez szögeltette turbánját. (Más források szerint ezt több török követtel is megcselekedte - a követekkel különben is igen kegyetlenül bánt, tekintet nélkül megbízóikra.)

A szultán válasza nem váratott sokáig magára. 1469-ban II. Mehmed (Konstantinápoly meghódítója) bosszúhadjáratot indított Dracula ellen. A vajda mérföldekre menekült a törökök elöl, maga mögött felégette a falvakat, és megmérgezte a kutak vizét. A teljesen kimerült éhes és szomjúságtól kínzott török had egyszerre csak 20000 török katona nyársra húzott tetemével szembesült. Vlad korábban mindet karóba húzatta. Ez volt a hírhedt „Vlad erdeje” nevü vérmező. Dracula ezt a kivégzési módszert különösen kedvelte, így kapta másik, Tepeş (Nyársas) melléknevét.

A szultán elborzadva visszavonult. De annyi ereje és bölcsessége még maradt, hogy Vlad öccsének, Radunak ajándékozza Havasalföldet. Így sikerült Radut bátyja ellen fordítania. Radu a szultánnál hatékonyabban és nagyobb helyismerettel fogott a háborúba, el is kergette Vladot, aki Mátyáshoz menekült. Dracula fivére - a korábban már bevált, és a későbbi korok román külpolitikájában is gyakorta alkalmazott módszerrel - titkos megegyezést kötött Mátyással is: ennek részeként átadta Vlad azon levelét a királynak, amelyet Dracula a Mátyással való szövetség

\footnotetext{
${ }^{15}$ Az eredeti latin szövegủ jelentést lásd: Fraknói Vilmos tanulmányában. [8]
} 
megkötése után írt a szultánnak. ${ }^{16}$ (Ám Radu sem ért meg túl hosszú időt a trónon: a szintén török segítséggel trónra kerülő Dăneşti család-a szokásos trágyadomb alá - élve eltemettette.)

Mátyás - a szász városok panaszára hallgatva és Radutól szerzett értesülései miatti dühében - elfogatta Vladot, és Visegrádon bebörtönözte. Dracula 1476-ban máig tisztázatlan módon, még utoljára kiszabadult, és Báthory István erdélyi vajda segítségével visszafoglalta Havasalföldet öccse utódjától, az öreg Dăneşti Basarabtól. Hűséges bojárjai egy újabb török had közeledtének hírére meggyilkolták, és maradványait Mátyáshoz juttatták. Mátyás Vlad ecetben és mézben tartósított tetemét és levágott fejét elküldte a törököknek. Azok mindkét testrészt karóba húzva tették közszemlére, így bizonyítván hatalmukat az ördög felett. [15]

Halála után azonnal mendemondák kaptak lábra: iszonyú bủnei miatt sem az Isten nem türte meg az égben, sem az ördög a pokolban, ezért a földön bolyong, és az elevenek vérét szipolyozva tartja fönt nyomorult létezését. ${ }^{17}$ A toposz hatása annyira erős volt, hogy Nicolae Ceaușescu (1918 - 1989) román diktátor tetemét, miután 1989. dec. 25-én Târgoviștében(!) kivégezték, a televízió előtt ülő milliók szeme láttára vizsgálták meg, nem mutatkoznak-e rajta vámpírjegyek.

Stoker Drakulája magán viseli a történelmi Dracula vonásait. Többször is hangsúlyozza bajuszát, hatalmas testi erejét, ördögi ravaszságát és vakmeröségét. Az első olyan gonosz, akiben - hátborzongató, sőt iszonytató vonásai mellett - kétségkívül van egyfajta méltóság, bár alakját vonzónak semmiképpen sem nevezhetnénk.

\section{Irodalmi elöd: Polidori doktor és Byron vámpírja}

A nagy formátumú, arisztokratikus vérszívó (amelynek megjelenése az első lépés volt a vámpír humanizálása felé) Mary Shelley Frankensteinje kapcsán már emlegetett John Polidori tollából született meg. (A vámpír, 1819) A doktort ellentmondásos kapcsolat füzte Lord Gordon Byronhoz, akinek háziorvosa volt. Byron hol támogatásáról biztosította, hol kigúnyolta alkalmazottját annak irodalmi ambíciói miatt. Polidori sajátos bosszút állt: Byronból vámpírt faragott.

A történet szerint Lord Ruthven (aki a leírás szerint erösen Byront formázza) nagy sikereket arat a társaságban ékesszólásával és spleenjével. Különösen a hölgyeket bűvöli el. Egy lelkes fiatalember, Mr. Aubrey, teljesen a Lord befolyása alá kerül, aki magával viszi öt egy görögországi utazásra. Ennek folyamán a Lord meghal, de Aubrey-t elötte megesketi, hogy halálát egy évig titokban tartja otthon. Aubrey esküt tesz, hazaérve azonban megdöbbenve tapasztalja, hogy Lord Ruthven nagyon is életben van, és éppen esküvőre készül - Aubrey húgával. A szerencsétlen fiatalember teljesen kétségbe esik, de köti esküje...

Ennek a vámpírnovellának a végjátéka is eléggé hátborzongató. Polidori doktor halogatta a megjelentetését (talán a közben elhunyt Byron emlékére tekintettel), de amikor visszatért Angliába, szembesülnie kellett azzal, hogy egy újságíró saját neve alatt kiadta múvét, és szép sikereket aratott vele. Polidori felháborodásában beperelte, ekkor azonban arcába vágták, hogy Byron emlékéből akart hasznot húzni. Végül elkeseredésében ciánt ivott, és meghalt. A szerencsétlen doktor mindössze 25 éves volt. [3] Stoker - Drakulája megformálásakor - valószínüleg fölhasználta Polidori ötleteit is a karakterépítéshez.

\footnotetext{
16 Íme, az inkriminált levél:

„Mindazon császárok császárát és uralkodók uralkodóját, akik csak élnek a Nap alatt, Mohamedet, a minden tettében szerencsés nagy Murádot és nagy szultánt alázatos hódolattal köszönti lon vajda, Havasalföld ura.

Én, hatalmas birodalmad rabszolgája, tudatom veled, hogy ma seregemmel a magam földjére indulok, s bízom Istenben, hogy ha parancsod meg nem akadályoz benne, akkor meg is szerzem azt. Alázatosan kérem tehát Nagyságodat, hogy ne tekintsd eltévelyedésemet és súlyos vétkemet, hiszen oktalanságomban vétkeztem ellened s cselekedtem gonoszságot a földeden -, hanem könyörüljön meg rajtam kegyességed, s engedje meg, hogy elküldhessem hozzád követeimet.

Ismerem Erdély egész területét és egész Magyarországot, tapasztalatokat szereztem földjéről és belső helyzetéröl egyaránt. Ha Császár Nagyságod beleegyezik, vétkemért engesztelésül Erdély egész földjét a kezedbe helyezhetem, ha pedig azt birtokba vetted, már egész Magyarországot hatalmad alá vetheted. A továbbiakat követeim fogják ismertetni elötted.

Én, amíg csak élek, töretlen hüségü szolgád leszek. Isten sokáig éltesse hatalmas birodalmadat!

Kelt Rethelben 1462. november 10-én."

(Aeneas Sylvius Piccolomini, II. Piusz néven pápa Feljegyzései, részlet) idézi: Von Birken, Marianna [25]

17 Külön tanulmány szól arról, hogy milyen kegyetlenkedéseket kapcsoltak korabeli, 15. századi röplapok Dracula alakjához, és hogyan lett ö természetfeletti szörnyeteggé. Bővebben lásd: W. Salgó Ágnes tanulmányában. [26]
} 


\section{Filmes feldolgozások}

Az első film magyar alkotó munkája. Lajthay Károly 1921-ben Drakula halála címmel dolgozta fel Stoker ötletét. (Hazánkban 1923-ban mutatták be először.) Azonban Lajthay - a szerzői jogi perek elkerülése érdekében - alaposan átgyúrta a történetet. A föhős Mary Land, egy fiatal lány, aki meglátogatja édesapját egy tébolydában. Az ápoltak közt felismeri egykori zenetanárát, aki Drakulának képzeli magát. A lány lidérces álmában megjelenik Drakula, aki erdélyi kastélyába hurcolja őt, hogy ott asszonyává tegye. Sajnos a film kópiái a II. Világháborúban megsemmisültek, a történetet a forgatókönyv alapján írt lektürből ismerjük. A „filmregény” szerzője, Pánczél Lajos, egy Lugosi Béla nevű magyar színész barátja volt. Utóbbi később Hollywoodban szerzett magának hírnevet, a mindmáig ikonikus Dracula c. film föszerepével.

Az USA-beli földolgozás előtt azonban még egy német némafilmes adaptációja is elkészült Stoker történetének, a Nosferatu (1922). A filmet a német expresszionizmus egyik legjobb mozgókép-dokumentumaként tartják számon. Rendezője Friedrich Wilhelm Murnau. Bár a jogörökösök érzékenységére tekintettel a cselekményt egy német kikötővárosba helyezték át, $s$ a föszereplök is új nevet kaptak, Stoker özvegye, a szépségéröl híres Florence Balcombe azonnal jogdíjpert indított, amit 1925-ben meg is nyert. Bár anyagi kártérítést nem kapott, de kötelezte a film alkotóit a kópiák megsemmisítésére. Végül azonban mégis előbukkantak használható másolatok, és Murnau munkája máig úgy ismert, mint a filmtörténet egyik jelentös darabja. Nosferatu csöppet sem rokonszenves: félelmetes, visszataszító, kopasz, denevérfülű figura, akinek az árnyéka mintegy önálló életet él. A vámpírizmus a filmben mint szörnyü ragály jelenik meg, mely az egész emberiség jövőjét veszélyezteti. A legnagyobb formátumú alak a történetben a női föszereplö, Ellen Hutter, aki saját vérét ajánlja fel a szörnynek, és sikerül őt pirkadatig magánál tartania. A felkelő nap sugarai elpusztítják Nosferatut.

Minden idők leghíresebb filmes adaptációja, a Dracula 1931-ben készült el. Rendezője, Tod Browning megformálta a vámpírgróf karikatúrákból ismert alakját, a hatalmas fekete felleghajtójába burkolózó, ódon eleganciájú, brillantintól csillogó hajú kifinomult arisztokratáét, akit Lugosi Béla alakított máig ható erővel. Az angolt magyaros akcentussal beszélő, fenyegetően nyájas rém óriási hatást tett a későbbi mozgóképes és irodalmi feldolgozásokra is. Lugosi Draculáját nem lehetett kikerülni: jó ideig az ő epigonjaival vagy eröltetett ellentétkaraktereivel tudtak csak vámpírtörténet kreálni. Ezen a helyzeten végül Francis Ford Coppola: Bram Stoker's Dracula (1992, Magyarországon Drakula címen ismert) mozifilmje változtatott. ${ }^{18}$

Coppola alkotásában a szörny számtalan alakban jelenik meg: iszonyú bestiaként, sármos ifjú úriemberként, idötlenül vén, XVIII. századi arisztokrataként. Láthatóan szinte mindenható, vörös szeme időnként a lenyugvó napkorong mögül figyeli áldozatait. Azonban mégis szánalomra méltó és méltóságteljes karakter. Coppola a nyilvánvalóan elmebeteg és szadista Vlad Drăculea vajdából törökverő hőst formál, akinek a kedvese, Elizabeta, holtnak véli a férfit, és öngyilkos lesz. Mivel a görögkeleti egyház megtagadja Elizabeta egyházi temetését, Dracula örjöngö dühében megátkozza Krisztust és az egyházat, s büntetésböl szörnnyé válik. Különösen visszatetsző a film föloldozásnak szánt - befejezése, amelyben - Dracula elpusztítása után - menyasszonya karján, az üdvözültek seregében lebegő boldog lélekként látjuk azt a szörnyet, aki emberek ezreit gyilkolta meg. Coppola alkotása utat nyitott a vámpírok „rehabilitációja” felé: egyre gyakoribbá vált a „jó” de legalábbis „jó szándékú” esetleg „bűnbánó” vérszopó figurája.

\section{Anne Rice: Interjú a vámpírral (1976)}

Az írónő Vámpírkrónikák c. sorozatának első darabjában egy Louis nevű jómódú lousianai ifjú telepesből lett vámpírral készít interjút egy megnevezetlen fiatalember. Rice vámpírjainak megmaradtak emlékei emberi életükről. Gondolkodó, etikus lények, akik tudatosan viselkednek etikátlanul, s emiatt néha lelkifurdalás gyötri öket. A regény másik föalakja, a kegyetlen Lestat, Louis megrontója, de még benne is van emberi érzelem, pl. saját vámpírrá válása után is évekig gondozza magatehetetlen, vak édesapját. A regény nagy sikert aratott, jókora rajongótáborral rendelkezik, hatásosságát csak fokozta, hogy 1994-ben hasonló címmel film is készült belöle. Fontos különbség a korábbi vámpírtörténetekhez képest, hogy Anne Rice vámpírjai már nem horrorfigurák, a

\footnotetext{
${ }^{18}$ A filmes feldolgozásokról lásd pl.: Kele-man cikkét. [13]
} 
Vámpírkrónikák már a fantáziairodalom, azon belül is a dark fantasyk - sötét fantáziák területére vezetnek bennünket. A vámpír örökifjú, hatalmas erejü lény, akinek ugyan távol kell tartania magát a nappal világától, de ezért a kis kényelmetlenségért bőven kárpótolja az öröklét mámora. A történet azt sugallja, hogy a vámpírizmus nem büntetés, nem betegség, voltaképpen jutalom és lehetőség a halandó ember számára, még akkor is, ha ehhez a jutalomhoz más emberek megölésével vezet az út.

Rice müködése eredményeként az élöhalottak ma már rajongók millióit vonzzák világszerte. Érdekes, hogy ez az eredetileg nagyon is "férfias” és csöppet sem vonzó világ mennyire magával ragadta a tinédzsereket, és köztük is a kamaszlányokat. Az efféle történetek (az utóbbi időben különösen pl. Stephenie Morgan Meyer Alkonyat-sorozata) valószínüleg azért lehetnek vonzók befogadóik számára, mert magukban hordozzák az ifjúsági regények két fontos témakörét: a szexualitás felfedezését és a felnőtté válás kérdéseit.

A Twilight típusú fantasy-regényekben szereplő vámpírok - többnyire jóképü, fiatalos külsejü férfiak - az átlagnál kifinomultabbak, müveltebbek, s ezt az előnyt öröklétük biztosítja a számukra. Ezek a kivételes lények aztán figyelmükkel ajándékozzák meg a regény főhősnőjét, akit lassan beengednek titokzatos és hátborzongató világukba. Ebben a környezetben mindig jelen van az üldözött szerelem motívuma, amely már az ókorban is bestsellerek sokaságát termelte ki (gondoljunk csak Héliodórosz: A sorsüldözött szerelmesek másképp Aithiopika esetleg Longosz: Daphisz és Chloé c. regényeire), a történetek középpontjában vagy a vámpír és az ember, vagy egyéb sötét lények, pl. vámpírok és vérfarkasok között szövődő tiltott kapcsolat áll.

Katona lldikó, az Alkonyat-sorozatot megjelentető a Könyvmolyképző Kiadó vezetője szerint:

„,bizonyos tekintetben megismétlődik a Harry Potter-jelenség. ... arról számolnak be az olvasók, hogy eddig sosem forgattak könyvet, ám amióta elolvasták az Alkonyatot, csak úgy falják a betüt. Tanároktól is kaptam üzenetet, megírták, hogyan akarják felhasználni akár a magyartanításban akár angoltanításban." [11]

Az olvasóvá nevelés mindennél fontosabbá válik napjainkban. Fölvetődik azonban az a kérdés, hogy a pedagógia számára kívánatos-e az olyan történetek kiválasztása, amelyek etikai háttere kérdéses, még akkor is, ha ebböl az a haszon származna, hogy tinédzsereket visszaültetné a könyvek mögé. Az Alkonyat világának vámpírjai Shakespeare-t olvasnak, Chopint hallgatnak. $\mathrm{A}$ Vámpírkrónikák számtalan irodalmi müvet idéz föl (irodalmi értéke is kétségtelenebb, mint Meyer könyveié), de az alapkérdés most is az marad, ami a vámpírtörténetek hajnalán már fölvetődött: elviselhetö-e az öröklét, ha cserébe magányos ragadozókká kell válni? Megengedhető-e a hatalom és a tudás megszerzése, ha ezt mások pusztulása árán érjük el? 


\section{Köszönetnyilvánítás}

Köszönetet mondunk a kutatás támogatásáért, amely az EFOP-3.6.1-16-2016-00006 „A kutatási potenciál fejlesztése és bővítése a Neumann János Egyetemen" pályázat keretében ment végbe. A projekt a Magyar Állam és az Európai Unió támogatásával, az Európai Szociális Alap társfinanszírozásával, a Széchenyi 2020 program keretében valósul meg. 


\section{Irodalomjegyzék}

[1] Bartha Tibor (szerk.) (1993): Keresztyén bibliai lexikon, Magyarországi Református Egyház Kálvin János Kiadója, Budapest [on-line] Avaliable: https://www.arcanum.hu/hu/online-kiadvanyok/Lexikonok-keresztyenbibliai-lexikon-C97B2/a-a-C97B4/animizmus-C989A/ [Megtekintés: 2019. 10. 23.]

[2] Bokor József (szerk.) (1998.): Pallas nagy lexikona VIII. Budapest, Arcanum, FolioNET Kft. 11278.p.

[3] Borbély Zsuzsa (2020.02.14.): 10 érdekesség a vámpírokról, in: fidelio [on-line] Avaliable: https://fidelio.hu/vizual/noi-vampir-verszivo-zenetanar-es-magyar-drakula-10-erdekesseg-a-vampirokrol152716.html [Megtekintés: 2020. 03. 05.]

[4] Dégh Linda (1957): Adalékok a „hálás halott” epizód mesei és mondai formálódásához, in: Ethnographia. pp. 307 - 318. 314. p.

[5] Deutsch Tibor (2015. 12. 01.): A Gólem legenda, in: Szombat. [on-line] Avaliable: https://www.szombat.org/hagyomany-tortenelem/a-golem-legenda [Megtekintés: 2019. 10. 23.]

[6] Dhwty: Nachzehrers (2016. 06. 01.): The Shroud Eating Vampires of Germanic Folklore, in: Ancient Origins. [on-line] Avaliable: https://www.ancient-origins.net/myths-legends/nachzehrers-shroud-eating-vampiresgermanic-folklore-006010 [Megtekintés: 2019. 12. 04.]

[7] EMIH (Köves Slómó) (2019): Gilgulim - A reinkarnációk könyve, in: zsido.com [on-line] Avaliable: https://zsido.com/fejezetek/gilgulim-a-reinkarnaciok-konyve/ [Megtekintés: 2019. 01. 20.]

[8] Fraknói Vilmos (1897): Miklós modrusi püspök élete, munkái és könyvtára, in: Magyar Könyvszemle, Új folyam 5. kötet, 1897. 1. füzet 13. p. [on-line] Avaliable: http://epa.oszk.hu/00000/00021/00096/pdf/001-023.pdf [Megtekintés: 2019. 11. 10.] 13. p.

[9] Galuska László Pál (2020): Tükör vagy görbe tükör, Pont Kiadó, Budapest. 81 - 84. p.

[10] Heitz, Markus: Vámpírok! Vámpírok! Minden, amit a vérszopókról tudni kell, Könyvmolyképző, Szeged, 2010. 94. p.; 107 - 114. p.; 39. p.; 34 - 44. p.; 78 -107. p.

[11] Herskovits Eszter (szerk.) (2009. 09. 14.): Biztonságos stresszkezelés vámpírokkal, in: 168 Óra. [on-line] Avaliable: https://168ora.hu/kultura/biztonsagos-stresszkezeles-vampirokkal-120152 [Megtekintés: 2019. 12. 20]

[12] Hume, Lynn \& McPhillips, Kathleen (edit.) (2006): Popular Spiritualities: The Politics of Contemporary Enchantment, Ashgate Publishing Limited, Aldershot, 20. p.

[13] Kele-man (2018. 06. 07.): A Drakula filmek evolúciója, in: Cinegore, A Magyar Horrorportál. [on-line] Avaliable: http://www.cinegore.net/2018/06/07/a-drakula-filmek-evolucioja/ [Megtekintés: 2020. 03. 15.]

[14] Kunt Ernő (1993): Temetési szokások, in: Ujváry Zoltán (szerk.): Magyar néprajz VII. pp. 67 - 101. Akadémiai, Budapest, 97 - 101. p.

[15] Pivárcsi István (2003): Drakula gróf és társai - Nagy vámpírkönyv, Palatinus, Budapest. 164 - 169. p.; 177 186. p.; 18. p.; 14 - 18. p.; $84-91$. p.

[16] Pócs Éva (1997): Élök és holtak, látók és boszorkányok. Mediátori rendszerek a kora újkor forrásaiban. Akadémiai Kiadó, Budapest. 36 - 37. p.; 34 - 36. p.

[17] Pócs Éva (2008. nov. 04.): Élők, holtak és a víz mitológiája (konferencia előadás), Magyar Tudomány Ünnepe, „A víz kultúrája” konferencia. [on-line] Avaliable: http://www.mta.hu/fileadmin/l_osztaly/eloadastar/A_viz_PocsE.pdf [Megtekintés: 2009. május 15.] 3. p.

[18] Pócs Éva (2002): Kereszteletlenek, zivatardémonok és az ördög, in: Magyar néphit Közép-és Kelet-Európa határán, L' Harmattan Kiadó. [on-line] Avaliable: http://www.tankonyvtar.hu/main.php?objectID=5321062 [Megtekintés: 2009. május 15.]

[19] Raj Tamás (2003. szeptember 11): A vér szerepe a Bibliában és a zsidó életben. A tiszaeszlári vérvád 120. évfordulója alkalmából rendezett tudományos konferencia előadás, Nyíregyháza, in: zsido.hu [on-line] Avaliable: http://www.zsido.hu/tortenelem/ver.htm [Megtekintés: 2019. 11. 02.]

[20] Ráth-Végh István (1982): A könyv komédiája, Gondolat. 338 - 350. p.; 338 - 339. p.

[21] Stoker, Bram (1985): Drakula gróf válogatott rémtettei (ford.: Bartos Tibor), Árkádia, Budapest. 20. p.

[22] Takács Gábor (2014. 04. 04.): Frankenstein, avagy a modern Prométheusz, in: Spaceman Spiff. [on-line] Avaliable: http://acelpatkany.blogspot.com/2014/04/mary-shelley-frankenstein.html [Megtekintés: 2019. 10. 14.]

[23] Tarján M. Tamás (2019): 1897. május 26. | Megjelenik Bram Stoker Drakula című regénye, in: Rubiconline [online] Avaliable:

http://www.rubicon.hu/magyar/oldalak/1897_majus_26_megjelenik_bram_stoker_drakula_cimu_regenye/ [Megtekintés: 2019. 10.11.]

[24] Tóth Béla (1984.): Mendemondák, A világtörténet furcsaságai, Helikon, Budapest. 12. p.

[25] Von Birken, Marianna (2009. 12. 19.): Dokumentumok Vlad Tepesröl - I. rész, in: Ekhanomidan, Es reiten die Toten so schnell. [on-line] Avaliable: http://ekhanomidan.blogspot.com/, [Megtekintés: 2020. 01. 15.]

[26] W. Salgó Ágnes: Drakula vajda története, 2002 [on-line] https://mek.oszk.hu/02400/02470/html/pages/tan.htm (Megtekintés: 2020. 10. 4.) 